\title{
How can farming intensification affect the environmental impact of milk production?
}

\author{
L. Bava, A. Sandrucci, ${ }^{1}$ M. Zucali, M. Guerci, and A. Tamburini \\ Dipartimento di Scienze Agrarie e Ambientali, Università degli Studi di Milano, Via Celoria 2, 20133 Milano, Italy
}

\begin{abstract}
The intensification process of the livestock sector has been characterized in recent decades by increasing output of product per hectare, increasing stocking rate, including more concentrated feed in the diet, and improving the genetic merit of the breeds. In dairy farming, the effects of intensification on the environmental impact of milk production are not completely clarified. The aim of the current study was to assess the environmental impacts of dairy production by a life cycle approach and to identify relations between farming intensity and environmental performances expressed on milk and land units. A group of 28 dairy farms located in northern Italy was involved in the study; data collected during personal interviews of farmers were analyzed to estimate emissions (global warming potential, acidification, and eutrophication potentials) and nonrenewable source consumption (energy and land use). The environmental impacts of milk production obtained from the life cycle assessment were similar to those of other recent studies and showed high variability among the farms. From a cluster analysis, 3 groups of farms were identified, characterized by different levels of production intensity. Clusters of farms showed similar environmental performances on product basis, despite important differences in terms of intensification level, management, and structural characteristics. Our study pointed out that, from a product perspective, the most environmentally friendly way to produce milk is not clearly identifiable. However, the principal component analysis showed that some characteristics related to farming intensification, such as milk production per cow, dairy efficiency, and stocking density, were negatively related to the impacts per kilogram of product, suggesting a role of these factors in the mitigation strategy of environmental burden of milk production on a global scale. Considering the environmental burden on a local perspective, the impacts per hectare were positively associated with the intensification level.
\end{abstract}

Received September 27, 2013.

Accepted March 16, 2014.

${ }^{1}$ Corresponding author: anna.sandrucci@unimi.it
Key words: milk production, intensive farming, environmental impact, life cycle assessment

\section{INTRODUCTION}

In recent decades, the European livestock sector has shown a general trend toward enlarging farm size and increasing intensification in terms of output per hectare. The intensification of production is generally characterized by increasing stocking rate, including more concentrated feed in the diet and improving the genetic merit of the breeds (Alvarez et al., 2008). Such evolution has also affected the Italian dairy sector, which has shown a strong decrease in the total number of dairy cows over the last $30 \mathrm{yr}$ (from 2.6 million in 1980 to 1.6 million presently) and an increase in the number of cows per farm (from 7.9 to 31.8 in the same period; ISTAT, 2012). Furthermore, in northern Italy, favorable climatic and infrastructure conditions have led to a very high livestock concentration with a consequent intensive utilization of natural resources (i.e., land, air, water) and high environmental pressure. Intensification of livestock production systems is generally considered detrimental from an environmental point of view. A study from New Zealand (Basset-Mens et al., 2009) showed that increasing the number of cows per land unit (with higher $\mathrm{N}$-fertilization and more land used to grow maize for silage instead of permanent grass) reduced dairy farm eco-efficiency in terms of both milk production and land use functions. Penati et al. (2011), assessing environmental sustainability of a group of alpine dairy farms, found that the best environmental performances were obtained by the farms characterized by low stocking density, low production intensity, high feed self-sufficiency, and large land availability in the valley floor. But other results from the literature showed some positive effects of the intensification of livestock production in terms of environmental impact mitigation. A review study by Crosson et al. (2011) concluded that increased output per hectare obtained through intensification can reduce emissions per kilogram of product. Kristensen et al. (2011) identified herd efficiency and farming intensity as relevant strategies for environmental impact reduction. Yan et al. (2013) 
found that, as milk production increases, a mitigation of environmental impact is observed. Casey and Holden (2005) suggested that, to improve the environmental efficiency of dairy farms, a move toward fewer cows producing more milk at lower stocking rates is required. This represents an extensification in terms of area but an intensification in terms of animal husbandry systems.

Life cycle assessment (LCA) is a generally accepted method for estimating the environmental impact of agricultural products on a global perspective. The main environmental effects quantified in LCA studies on dairy systems are the acidifying and eutrophic effects on watercourses, the global warming effect, and the utilization of resources such as land and nonrenewable energy during the production of milk (O'Brien et al., 2012).

Even if climate change is a global issue, for environmental aspects with a local connotation (especially acidification and eutrophication), environmental impact should be evaluated not only per unit of product but also per hectare of land. In particular, eutrophication pertains directly to the leaching and run-off of nitrate and phosphate to the ground and surface water; therefore, this parameter contains a local aspect (Oudshoorn et al., 2011). Many authors showed significantly worse environmental performances of the intensive livestock systems when the impacts were expressed in terms of land unit (Haas et al., 2001; Casey and Holden, 2005).

The first objective of the current study was to analyze the environmental performances of a sample of dairy farms, both on a global and on a local perspective, through an LCA approach. The second objective was to identify the relation between environmental impacts and main farm characteristics, focusing in particular on farming intensity.

\section{MATERIALS AND METHODS}

\section{System Description and Data Collection}

A group of 28 dairy cattle farms were involved in the current study. All the farms were located in northern Italy and were members of a cheese factory producing Grana Padano. All cows were Italian Holstein kept in permanent confinement without pasture. This rearing system is the most commonly used in the north of Italy.

Data were collected through personal interviews of farmers. Questions were addressed to obtain precise information about cropping systems and field operations, fuel consumption, number of animals and housing systems, and manure storage and animal rations. Moreover, data regarding the inputs entering the farms were acquired, including amount of purchased feeds (both roughages and concentrates), fertilizers and pesticides, bedding materials, and number and origin of purchased replacement animals.

In each farm, forages (hays and silages) and TMR were sampled and analyzed for the content of DM ash, $\mathrm{CP}$, ether extract, and crude fiber by AOAC International (1995) methods; starch by AOAC International (1998) methods; NDF analyzed following the protocol of Mertens (2002); and ADF and ADL by the method of Van Soest et al. (1991). Data obtained from the analyses were used for the estimation of digestibility of the feeding rations. The amount of milk produced by each farm was provided by the cheese factory, whereas the amount of meat (as animal liveweight) was estimated on the basis of the number of animals sold for slaughter and their liveweight declared by the farmers.

Composition of concentrated feed was estimated on the basis of the raw materials reported on the commercial labels using CPM-Dairy Ration Analyzer Beta V3 software (Cornell-Penn-Miner, 2004). Table 1 summarizes the inventory of the most important data used for impact assessment. All the data are expressed as the average value of the 28 dairy farms.

The income over feed cost (IOFC) was used as economic indicator of farm profitability, as proposed by Hutjens (2007), and it was calculated as the income from milk minus feeding costs (self-produced and purchased feed) per cow per day.

\section{Emission Estimation}

Greenhouse Gas Emissions On Farm. Table 2 shows the models used for on-farm greenhouse gas emission (GHG) estimation. Methane $\left(\mathrm{CH}_{4}\right)$ emissions from livestock enteric fermentations were estimated using an equation from Ellis et al. (2007). To convert the energy of enteric methane in kilograms of methane emitted, the factor $55.65 \mathrm{MJ} / \mathrm{kg}$ of $\mathrm{CH}_{4}$ (IPCC, 2006a) was used. Methane emissions from manure management were estimated using the Tier 2 method suggested by the Intergovernmental Panel on Climate Change (IPCC, 2006a). Volatile solid excretion was estimated considering gross energy of the diets $(\mathrm{kJ} / \mathrm{kg}$ of $\mathrm{DM})$ evaluated using an equation of Ewan (1989). Digestibility of the feed was estimated using a calculation model developed for each type of forage and concentrate feed on the basis of the equation proposed by INRA (2007). Feed nutritional characteristics were obtained from the laboratory analyses.

In the current study, animal nitrogen excretion was estimated as proposed by the IPCC (2006a) Tier 2 method considering the nitrogen intake (on the basis of $\mathrm{CP} \%$ of the diet) minus the nitrogen retained by the animals and excreted with milk. Nitrous oxide $\left(\mathrm{N}_{2} \mathrm{O}\right)$ 
Table 1. Inventory data (average of the 28 farms)

\begin{tabular}{|c|c|c|c|c|c|}
\hline Item & Unit & Mean & $\mathrm{SD}$ & Minimum & Maximum \\
\hline Farm land & ha & 40.7 & 27.8 & 8.5 & 120 \\
\hline Permanent grassland & $\%$ land & 52.1 & 23.8 & 12.9 & 100 \\
\hline $\mathrm{NE}_{\mathrm{L}}$ yield & $\mathrm{MJ} / \mathrm{ha}$ & 74,965 & 20,924 & 34,901 & 134,248 \\
\hline Nitrogen yield & $\mathrm{kg} / \mathrm{ha}$ & 180 & 38.2 & 103 & 238 \\
\hline $\mathrm{N}$ synthetic fertilizers & $\mathrm{kg} / \mathrm{ha}$ & 84.3 & 51.1 & 0.0 & 202 \\
\hline Dairy cows & $\mathrm{n}$ & 90.3 & 52.0 & 17.0 & 195 \\
\hline Livestock unit (LU) & $\mathrm{n}$ & 143 & 86.7 & 25.7 & 308 \\
\hline Milk production & $\mathrm{kg}$ of $\mathrm{FPCM}^{1} /$ cow per day & 27.1 & 4.3 & 18.1 & 35.4 \\
\hline Production intensity & $\mathrm{kg}$ of $\mathrm{FPCM} / \mathrm{ha}$ & 19,764 & 7,955 & 12,005 & 46,455 \\
\hline Meat production ${ }^{2}$ & $\mathrm{~kg} /$ farm per year & 130 & 45.6 & 53.1 & 223 \\
\hline \multicolumn{6}{|l|}{ Manure type } \\
\hline Solid manure & $\%$ & 40.3 & 38.0 & 0.0 & 100.0 \\
\hline \multicolumn{6}{|l|}{ Energy } \\
\hline Diesel use & $\mathrm{kg} / \mathrm{LU}$ per year & 88.6 & 21.3 & 54.0 & 141 \\
\hline Electricity use & KWH/LU per year & 211 & 79.9 & 52.3 & 336 \\
\hline
\end{tabular}

${ }^{1} \mathrm{FPCM}=$ fat- and protein-corrected milk.

${ }^{2}$ Liveweight sold.

emissions from manure storages occurred in direct and indirect forms, and in both cases they were estimated using the Tier 2 method from IPCC (2006a). Direct and indirect $\mathrm{N}_{2} \mathrm{O}$ losses from fertilizer application were estimated following the Tier 2 and Tier 1 methods suggested by IPCC (2006b), respectively; the amount of nitrogen applied to the soils from synthetic fertilizers and from manure (slurry and solid) plus the nitrogen from crop residues were accounted for in the estimation.

Carbon dioxide $\left(\mathrm{CO}_{2}\right)$ emissions from fuel combustion were estimated on the basis of fuel consumption of each farm. Emissions occurring during field operations (i.e., plowing, harrowing, sowing, harvesting, and so on) were estimated using the processes of the Ecoinvent (2007) database; whereas, for other fuel consumptions (i.e., use for feeding mixer), the emission factor used was $3.12 \mathrm{~kg}$ of $\mathrm{CO}_{2} / \mathrm{kg}$ of diesel, as proposed by Nemecek and Kägi (2007). Emissions from livestock respiration and the variation in soil carbon stocks were not accounted for.

Other Emissions On Farm. Table 3 reports the models used for the estimation of acidifying and eutrophic substances emitted on farm. Ammonia $\left(\mathrm{NH}_{3}\right)$ and nitrogen oxide (NOx) emissions that occur during animal housing, manure storage, and spreading were estimated following the method proposed by the European Environment Agency (EEA. 2009a,b) on the basis of the total amount of nitrogen excreted by the animals. The Tier 2 method used a mass flow approach based on the concept of a flow of total ammonia nitrogen through the manure management systems. The $\mathrm{NH}_{3}-\mathrm{N}$ and $\mathrm{NOx}$ emission factors, as a proportion of total ammonia nitrogen, were specific for each manure type (slurry or solid) and each step in manure handling (EEA, 2009a). The $\mathrm{NH}_{3}$ and NOx emitted during manure spreading and application of synthetic fertilizers were estimated following EEA (2009b) guidelines. The amount of nitrogen leached was estimated following the IPCC (2006b) model (Table 2). To estimate emissions of $\mathrm{PO}_{4}{ }^{3-}$, the amount of phosphorus lost in dissolved form to surface water (run-off) and leached was considered as proposed by Nemecek and Kägi (2007).

Off-Farm Processes. The emissions related to off-farm activities were calculated using LCA software, Simapro PhD 7.3.3 (PRé Consultants, 2012), and were modeled using the databases reported in Table 4. The processes considered included the production chain of commercial feed (from crop growing to feed factory processing), production of purchased forages and bedding material, rearing of purchased replacing heifers, production of chemical fertilizers and pesticides, and diesel and electricity used in the farms. Transportation was accounted for only in feed, bedding materials, and purchased replacement animals.

As farms bought a quota of their replacement heifers, a simplified LCA was performed to assess the impacts associated to heifer rearing, considering animals sold at 24 mo of age, average feed intake, average diet 
Table 2. Models and emission factors (EF) used for the estimation of greenhouse gas emissions on farm

\begin{tabular}{|c|c|c|c|}
\hline Pollutant & Source & Amount $^{1}$ & Reference \\
\hline \multirow[t]{8}{*}{$\mathrm{CH}_{4}$} & Enteric & $\begin{array}{l}\mathrm{CH}_{4}(\mathrm{MJ})=2.16( \pm 1.62)+0.493( \pm 0.192) \cdot \mathrm{DMI}(\mathrm{kg})-1.36( \pm 0.631) \cdot \mathrm{ADF}(\mathrm{kg}) \\
+1.97( \pm 0.561) \cdot \mathrm{NDF}(\mathrm{kg})\end{array}$ & Ellis et al. (2007) \\
\hline & Manure storage & $\mathrm{CH}_{4}=\mathrm{VS} \times \mathrm{B}_{0} \cdot 0.67 \cdot \mathrm{MCF} / 100 \cdot \mathrm{MS}$ & Equation 10.23 in IPCC (2006a) \\
\hline & & $\mathrm{VS}=[\mathrm{GE} \cdot(1-\mathrm{DE} / 100)+(\mathrm{UE} \cdot \mathrm{GE})] \cdot[(1-\mathrm{Ash}) / 18.45]$ & Equation 10.24 in IPCC (2006a) \\
\hline & & $\mathrm{GE}(\mathrm{kJ})=17,350+(234.46 \cdot \mathrm{EE} \%)+(62.8 \cdot \mathrm{CP} \%)-(184.22 \cdot \mathrm{Ash} \%)$ & Ewan (1989) \\
\hline & & DE: feed digestibility & INRA. 2007 \\
\hline & & MCF solid storage: 4 & IPCC (2006a) \\
\hline & & MCF liquid slurry: 17 & \\
\hline & & MCF pit storage: 27 & \\
\hline \multirow[t]{12}{*}{$\mathrm{N}_{2} \mathrm{O}$ direct } & Manure storage & $\mathrm{N}_{2} \mathrm{O}=\mathrm{Nex} \cdot \mathrm{MS} \cdot \mathrm{EF} \cdot 44 / 28$ & Equation 10.25 in IPCC (2006a) \\
\hline & & $\begin{array}{l}\text { Nex }=\text { Nintake } \cdot(1-\mathrm{N} \text { retention }) \\
\mathrm{N} \text { intake: DMI } \cdot(\mathrm{CP} \% / 100 / 6.25)\end{array}$ & Equation 10.31 in IPCC (2006a) \\
\hline & & $\mathrm{N}$ retention: $\mathrm{N}$ retained per animal with milk and weight gain & Equation 10.33 in IPCC (2006a) \\
\hline & & EF solid storage: $0.005(0.0027-0.01)$ & Table 10.21 in IPCC (2006a) \\
\hline & & EF liquid slurry: 0.005 & \\
\hline & & EF pit storage: 0.002 & \\
\hline & Field & $\mathrm{N}_{2} \mathrm{O}=(\mathrm{Nsn}+\mathrm{Non}+\mathrm{Ncr}) \cdot \mathrm{EF} \cdot 44 / 28$ & Equation 11.2 in IPCC (2006b) \\
\hline & & Non: annual amount of $\mathrm{N}$ from managed animal manure applied to soil ( $\mathrm{Nex}-$ Frac_loss $+\mathrm{N}$ bedding) & Equation 10.34 in IPCC (2006a) \\
\hline & & Frac_loss solid storage: $40 \%(10-65)$ & Table 10.23 in IPCC (2006a) \\
\hline & & Frac_loss liquid slurry: $40 \%(15-45)$ & \\
\hline & & Frac_loss pit storage: $28 \%(10-40)$ & \\
\hline & & $\mathrm{EF}: 0.01(0.003-0.03)$ & Table 11.1 in IPCC (2006b) \\
\hline \multirow[t]{11}{*}{$\mathrm{N}_{2} \mathrm{O}$ indirect } & Manure storage & $\mathrm{N}_{2} \mathrm{O}_{\mathrm{G}}=\mathrm{N}$ volatilization $\cdot \mathrm{EF} \cdot 44 / 28$ & Equation 10.27 in IPCC (2006a) \\
\hline & & $\begin{array}{l}\text { Nvolatilization: Nex } \cdot \text { MS } \cdot \text { Frac_GasMS } / 100 \\
\text { Frac_GasMS solid storage: } 30(10-40)\end{array}$ & Table 10.22 in IPCC (2006a) \\
\hline & & Frac_GasMS liquid slurry: $40(15-45)$ & 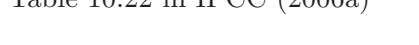 \\
\hline & & Frac_GasMS pit storage: $28(10-40)$ & \\
\hline & & EF: $0.01(0.002-0.05)$ & Table 11.3 in IPCC (2006b) \\
\hline & Field & $\mathrm{N}_{2} \mathrm{O}_{(\text {ATDN })}=[($ Nsn $\cdot$ Frac_GasF $)+($ Non $\cdot$ Frac_GasM $)] \cdot E F \cdot 44 / 28$ & Equation 11.9 in IPCC (2006b) \\
\hline & & Frac_GasF: $0.1(0.03-0.3)$ & Table 11.3 in IPCC (2006b) \\
\hline & & Frac_GasM: $0.2(0.05-0.5)$ & Table 11.3 in IPCC (2006b) \\
\hline & & EF: $0.01(0.002-0.05)$ & Table 11.3 in IPCC (2006b) \\
\hline & & $\begin{array}{l}\mathrm{N}_{2} \mathrm{O}_{(\mathrm{L})}=(\mathrm{Nsn}+\text { Non }) \cdot \text { Frac_Leach } \cdot \mathrm{EF} \cdot 44 / 28 \\
\text { Frac_Leach: } 0.3(0.1-0.8)\end{array}$ & Equation 11.10 in IPCC (2006b) \\
\hline & & $\mathrm{EF}: 0.0075(0.0005-0.025)$ & Table 11.3 in IPCC (2006b) \\
\hline \multirow[t]{2}{*}{$\mathrm{CO}_{2}$} & Field operations & & Ecoinvent (2007) \\
\hline & Diesel combustion $^{2}$ & $\begin{array}{l}\mathrm{CO}_{2}=\mathrm{kg} \text { diesel } \cdot \mathrm{EF} \\
\mathrm{EF}: 3.12 \mathrm{~kg} \text { of } \mathrm{CO}_{2} / \mathrm{kg} \text { of diesel }\end{array}$ & Nemecek and Kägi (2007) \\
\hline
\end{tabular}

${ }^{1} \mathrm{VS}=$ daily volatile solid excreted ( $\mathrm{kg}$ of $\mathrm{DM} /$ animal); $\mathrm{B}_{0}=$ maximum methane-producing capacity for manure $\left(\mathrm{m}^{3}\right) ; \mathrm{MCF}=$ methane conversion factors for each given manure management system (\%); MS = fraction of livestock manure handled using each given manure management system (dimensionless); GE $=$ gross energy intake $(\mathrm{MJ} / \mathrm{d}) ; \mathrm{DE} \%=$ energy digestibility of feed (\%); (UE - GE) = urinary energy expressed as fraction of GE (dimensionless); EE\% = ether extract of feed (\% DM); Nex = annual $\mathrm{N}$ excretion (kg of $\mathrm{N}$ /animal): $\mathrm{EF}=$ emission factor for direct $\mathrm{N}_{2} \mathrm{O}$ emissions from a given manure management system $\left(\mathrm{kg}\right.$ of $\mathrm{N}_{2} \mathrm{O}-\mathrm{N} / \mathrm{kg}$ of $\mathrm{N}$ in manure management system); Nsn = annual amount of synthetic fertilizer $\mathrm{N}$ applied to soils ( $\mathrm{kg}$ of $\mathrm{N}$ ); Non = annual amount of animal manure, compost, sewage sludge and other organic $\mathrm{N}$ additions applied to soils ( $\mathrm{kg}$ of $\mathrm{N}$ ); Ncr $=$ annual amount of $\mathrm{N}$ in crop residues (above and below ground), including N-fixing crops, and from forage/pasture renewal, returned to soils (kg of $\mathrm{N}$ ); Frac_loss = fraction of managed manure $\mathrm{N}$ that is lost in a given manure management system (\%); N_bedding = annual amount of $\mathrm{N}$ from bedding (kg of $\mathrm{N} /$ animal); $\mathrm{N}$ volatilization = annual amount of manure $\mathrm{N}$ that is lost due to volatilization of $\mathrm{NH}_{3}$ and nitric oxide compounds $\left(\mathrm{NOx}\right.$; $\mathrm{kg}$ of $\mathrm{N}$ ); Frac_GasMS = fraction of managed manure $\mathrm{N}$ that volatilizes as $\mathrm{NH}_{3}$ and $\mathrm{NOx}_{\text {in }}$ a given manure management system (\%); Frac_GasF = fraction of synthetic fertilizer $\mathrm{N}$ that volatilizes as $\mathrm{NH}_{3}$ and $\mathrm{NOx}(\%)$; Frac_GasM $=$ fraction of applied organic $\mathrm{N}$ fertilizer materials and of urine and dung $\mathrm{N}$ deposited by grazing animals that volatilizes as $\mathrm{NH}_{3}$ and $\mathrm{NOx}$ (\%); Frac_Leach = $\mathrm{N}$ fraction lost through leaching and runoff (\%).

${ }^{2}$ Excluding the quota used during field operations. 
Table 3. Models and emission factors (EF) for the estimation of ammonia, nitric oxide, and phosphate emissions on farm

\begin{tabular}{|c|c|c|c|}
\hline Pollutant & Source & Amount $^{1}$ & Reference \\
\hline $\mathrm{PO}^{3-}{ }_{4}$ & $\begin{array}{l}\text { Manure storage } \\
\text { Field } \\
\text { Field }\end{array}$ & 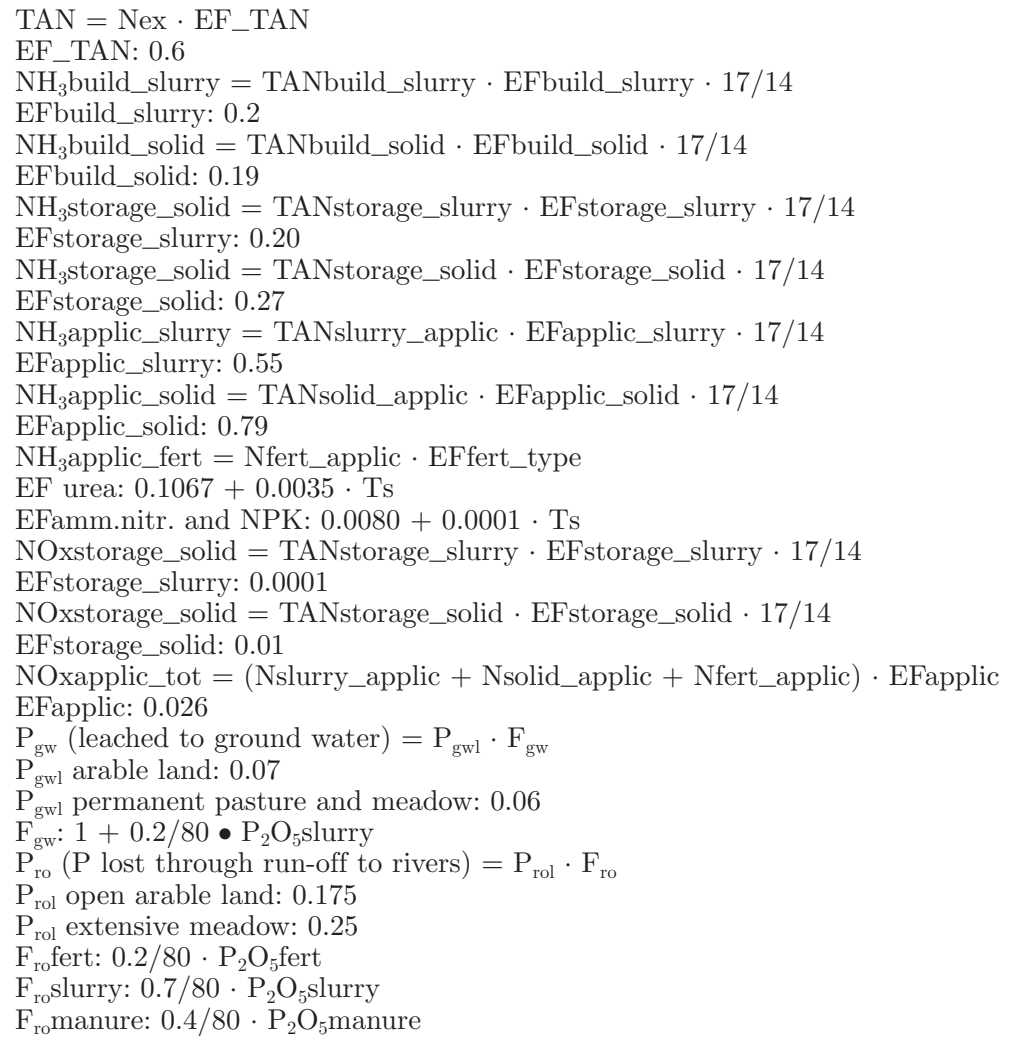 & $\begin{array}{l}\text { Equation } 10 \text { in EEA (2009a) } \\
\text { Table } 3-8 \text { in EEA }(2009 a) \\
\text { Equation } 15 \text { in EEA }(2009 a) \\
\text { Table } 3-8 \text { in EEA }(2009 a) \\
\text { Equation } 16 \text { in EEA (2009a) } \\
\text { Table } 3-8 \text { in EEA }(2009 a) \\
\text { Equation } 29 \text { in EEA (2009a) } \\
\text { Table } 3-8 \text { in EEA }(2009 a) \\
\text { Equation } 30 \text { in EEA (2009a) } \\
\text { Table } 3-8 \text { in EEA (2009a) } \\
\text { Equation } 35 \text { in EEA (2009a) } \\
\text { Table } 3-8 \text { in EEA }(2009 a) \\
\text { Equation } 36 \text { in EEA (2009a) } \\
\text { Table } 3-8 \text { in EEA }(2009 a) \\
\text { Equation } 3 \text { in EEA (2009b) } \\
\text { Table } 3-2 \text { in EEA (2009b) } \\
\text { Equation } 29 \text { in EEA (2009a) } \\
\text { Table } 3-9 \text { in EEA (2009a) } \\
\text { Equation } 30 \text { in EEA (2009a) } \\
\text { Table } 3-9 \text { in EEA (2009a) } \\
\text { Table } 3-1 \text { in EEA (2009b) } \\
\text { Paragraph } 4.4 .3 \text { in Nemecek and Kägi (2007) }\end{array}$ \\
\hline
\end{tabular}

${ }^{1}$ TAN = total ammoniacal-N; Nex = annual average N excretion per head ( $\mathrm{kg}$ of N/animal); EF_TAN = emission factor of TAN; build_slurry = liquid slurry in the livestock buildings; build_solid = solid manure in the livestock buildings; storage_solid = solid manure in storages; storage_slurry = liquid slurry in storages; applic_slurry = application of liquid application; EF fert type = emission factor for fertilizer type; Amm nitr = ammonium nitrate; NPK $=$ nitrogen-phosphorus-potassium fertilizer; Ts = mean spring temperature $\left({ }^{\circ} \mathrm{C}\right) ; \mathrm{NOx}=$ nitric oxide compounds $\left(\mathrm{NO}+\mathrm{NO}_{2}\right) ; \mathrm{P}_{\mathrm{gw}}=$ quantity of phosphorus leached to ground water $(\mathrm{kg} / \mathrm{ha}) ; \mathrm{P}_{\mathrm{gwl}}=$ average quantity of phosphorus leached to ground water $\Phi$ for each land use category $(\mathrm{kg} / \mathrm{ha}) ; \mathrm{F}_{\mathrm{gw}}=$ correction factor for fertilization by slurry; Pro = quantity of phosphorus lost through runoff to rivers ( $\mathrm{kg} /$ ha); $\mathrm{P}_{\text {rol }}=$ average quantity of phosphorus lost through runoff to rivers for each land use category $(\mathrm{kg} / \mathrm{ha})$; Fro = correction factor for fertilization with each source of phosphorus. 
Table 4. Inventory of off-farm processes

\begin{tabular}{ll}
\hline Process & Reference \\
\hline Feed production & Ecoinvent, 2007; Baldoni and Giardini, 2002; Ribaudo, 2002; data from the current study \\
Crop & Nielsen et al., 2007 \\
Milk powder & Nielsen et al., 2007 \\
Feed processing & Ecoinvent, 2007; Baldoni and Giardini, 2002; Ribaudo, 2002; data from the current study \\
Forage production & Ecoinvent, 2007 \\
Bedding material production & Data from the current study \\
Rearing animals & Patyk and Reinhardt, 1997; Ecoinvent, 2007 \\
Fertilizer production & Ecoinvent, 2007 \\
Pesticide production & Ecoinvent, 2007 \\
Energy production & Ecoinvent, 2007 \\
Transportation &
\end{tabular}

composition, standard housing conditions, and manure management.

\section{Impact Assessment}

The environmental impact of milk production in each dairy farm was evaluated through a detailed cradleto-farm-gate LCA (Belflower et al., 2012). The system boundaries included all the on-farm processes plus the off-farm activities linked to the production of external inputs (Figure 1).
The selected environmental impact categories were global warming, acidification, eutrophication, nonrenewable energy use, and land use (O'Brien et al., 2012). The impact assessment was performed with the EPD (2008) 1.03 method, updated with IPCC (2007) globalwarming potential (GWP) conversion factors (100-yr time horizon). Land use was estimated on the basis of total area (on- and off-farm land).

On a global perspective the functional unit (FU) was established as $1 \mathrm{~kg}$ of fat- and protein-corrected milk (FPCM) leaving the farm gate (Thomassen et

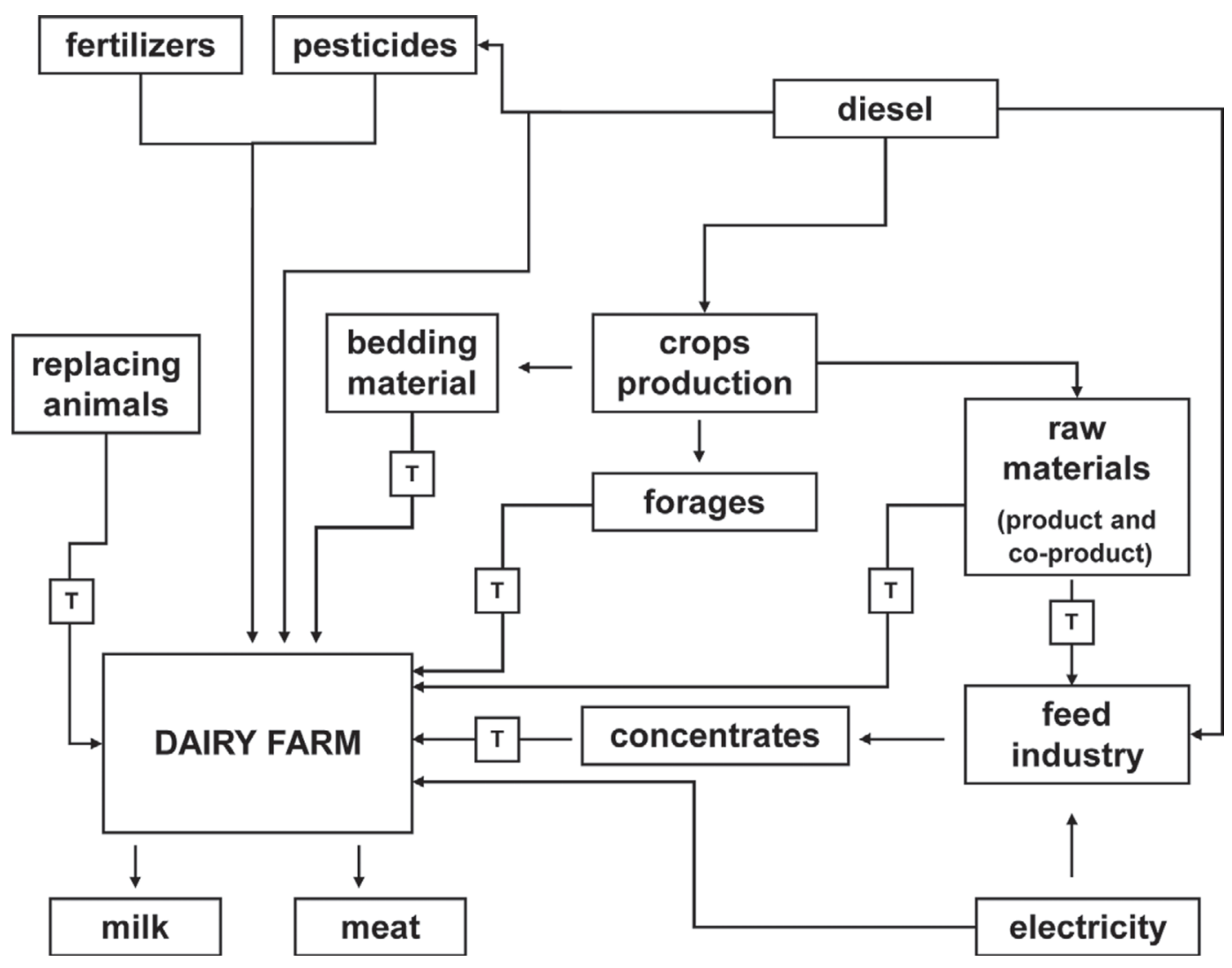

Figure 1. System boundaries. $\mathrm{T}=$ transportation. 
al., 2008) estimated using the formula FPCM $(\mathrm{kg})=$ raw milk $(\mathrm{kg}) \times(0.337+0.116 \times \%$ fat $+0.060 \times \%$ protein) from Gerber et al. (2010). The biological allocation method developed by IDF (2010) for the dairy farming system was calculated using the formula $\mathrm{AF}=$ $1-5.7717 \times \mathrm{R}$, where AF = allocation factor for milk; $\mathrm{R}=\mathrm{M}$ meat $/ \mathrm{M}$ milk; $\mathrm{M}$ meat $=$ sum of liveweight of all animals sold, including bull calves and culled mature animals; and M milk = sum of sold FPCM. The environmental impacts were also estimated from a local point of view, assuming 1 ha of farm land as FU.

\section{Statistical Analysis}

Statistical analysis was performed using SAS 9.2 software (SAS Institute, 2001) and was carried out in 3 steps. The first step was performed through a principal component analysis (PCA; PROC PRINCOMP) to study the relationships among total environmental impacts per kilogram of milk and per hectare, their on-farm contributions, and several quantitative variables related to farming intensity, including production level ( $\mathrm{kg}$ of $\mathrm{FPCM} / \mathrm{cow}$ per day), dairy efficiency ( $\mathrm{kg}$ of FPCM $/ \mathrm{kg}$ of DMI), number of dairy cows, stocking rate as livestock units (LU; LU/ha), total farm land (ha), shares of maize land for silage and grassland on total farm land, and IOFC ( $€ /$ cow per day). In the second step, farms were grouped through a CLUSTER procedure (using average linkage method) considering as variables total farm land (ha), number of dairy cows, stocking rate (LU/ha), production level (kg of FPCM/ cow per day), percentage of grass hay and maize silage on DMI, percentage of maize land for silage on farm land, dairy efficiency ( $\mathrm{kg}$ of $\mathrm{FPCM} / \mathrm{kg}$ of DMI), and feed self-sufficiency (expressed as the ratio between the DM produced on farm and the total DM used for animal feeding). For each cluster, average farm characteristics and environmental impacts on a global (FU $=1 \mathrm{~kg}$ of $\mathrm{FPCM})$ and local (FU = 1 ha of farm land) scale were computed. Moreover a Pearson correlation analysis was used to identify the relationship between farm characteristics and each environmental impact expressed per hectare of farm land.

\section{RESULTS}

\section{Environmental Impacts of Milk Unit}

Table 5 reports the average results of the environmental impact assessment of milk production in the farms under consideration expressed per milk unit. The on-farm percentage of GHG emissions was much higher compared with the off-farm one. The most important contributor to global warming was enteric and manure storage emission $(52.9 \pm 4.40 \%)$, followed by emissions related to the production of concentrated feed $(19.9 \pm 6.78 \%)$. Almost all the acidification was due to on-farm activity and the main role was played by farm crop production $(39.1 \pm 8.54 \%)$, animal housing $(22.7 \pm 2.63 \%)$, and manure storage $(22.5 \pm 5.25 \%)$. Also, for eutrophication, on-farm contribution was the most important factor; in particular, farm crop production was the major driver $(51.6 \pm 7.89 \%)$, whereas, in off-farm processes, the production of concentrate feed accounted for $21.2 \pm 7.66 \%$ of total eutrophication potential. In nonrenewable energy use, the on- and off-farm contributions were similar; the production of concentrated feed covered $46.6 \pm 13.9 \%$ of the total energy consumption alone. Similar to energy consumption, land use did not show any important difference between on- and off-farm shares; crop production for purchased concentrated feed contributed $33.0 \pm 10.8 \%$ of total impact alone, followed by growing of purchased forages $(5.82 \pm 7.58 \%)$.

Figure 2 shows the average contributions of different substances to GWP, acidification, and eutrophication. Overall, methane was responsible for $49.9 \pm 3.64 \%$ of total GHG emission, followed by carbon dioxide and nitrous oxide, which had similar weights $(25.4 \pm 2.59$ and $24.5 \pm 3.25 \%$, respectively). Enteric fermentation

Table 5. Total environmental impacts expressed per kilogram of fat- and protein-corrected milk (FPCM) for the 28 dairy farms and on-farm contributions

\begin{tabular}{|c|c|c|c|c|c|}
\hline Environmental impact & Location & Mean & $\mathrm{SD}$ & Minimum & Maximum \\
\hline Global warming ( $\mathrm{kg}$ of $\mathrm{CO}_{2}$-equivalent) & On-farm \% & 74.3 & 7.05 & 61.1 & 87.8 \\
\hline Acidification ( $\mathrm{g}$ of $\mathrm{SO}_{2}$-equivalent) & Total & 15.2 & 3.34 & 8.63 & 21.7 \\
\hline \multirow[t]{2}{*}{ Eutrophication ( $\mathrm{g}$ of $\mathrm{PO}_{4}$-equivalent) } & Total & 7.33 & 1.39 & 5.00 & 9.69 \\
\hline & On-farm \% & 74.6 & 8.10 & 59.5 & 90.3 \\
\hline Energy use (MJ) & Total & 5.47 & 0.89 & 2.85 & 7.33 \\
\hline Land use $\left(\mathrm{m}^{2}\right)$ & On-farm \% & 58.1 & 12.4 & 40.1 & 83.1 \\
\hline
\end{tabular}


4586

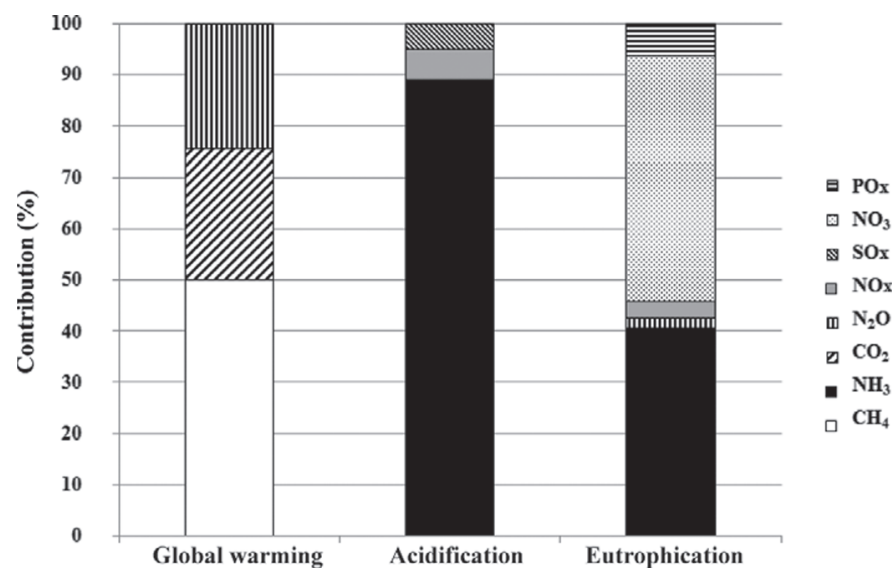

Figure 2. Contribution of different substances to the impact categories.

was the most important source of $\mathrm{CH}_{4}$, as $74.3 \pm 8.87 \%$ of total methane was produced in the gastrointestinal tract of the animals.

Ammonia emission accounted for $88.8 \pm 2.34 \%$ of acidification potential. Ammonia volatilized mainly during application of manure on farm soils (41.4 \pm $9.36 \%$ of total ammonia emission) and during animal housing and manure storage $(25.6 \pm 2.87$ and $25.1 \pm$ $5.66 \%$ of total ammonia emission, respectively). Nitrate leaching was the main contributor to eutrophication potential $(47.8 \pm 4.01 \%)$, followed by volatilized $\mathrm{NH}_{3}$ $(40.3 \pm 4.61 \%)$, whereas the role of phosphate losses was less important (only $6.13 \pm 1.43 \%$ ). The percentage of nitrate leached during on-farm crop production was higher than the fraction related to purchased feed (concentrates and forages), at $67.1 \pm 10.4$ and $29.6 \pm$ $10.9 \%$ of total nitrogen leached, respectively.

\section{Interaction Between Farm Characteristics and Environmental Impact}

The results obtained from the PCA are plotted in Figures 3 and 4 and the eigenvectors are reported in Tables 6 and 7. Figure 3 shows the multivariate correlation between farm characteristics and environmental impacts per kilogram of FPCM. The first dimension explains $38.7 \%$ of the total variance, whereas the second dimension explains $20.1 \%$. Total impacts [total global warming (GWtot), total land use (LANDtot), and total energy use (ENERGYtot)] and their on-farm quotas, expressed in terms of kilograms of milk produced, are in the same area and highly correlated with each other and with feed self-sufficiency. On-farm land use and on-farm energy use are strongly related to feed self-sufficiency because the higher the quota of feed produced on farm, the higher their impact. Total and on-farm acidification and eutrophication are very close to the percentage of land used for maize silage production, which needs high $\mathrm{N}$ fertilization.

The farm characteristics enclosed in the upper-left area of Figure 3 are inversely related to the total impact per kilogram of milk. The distance between the variables on the first dimension of the graph means that improving milk production and dairy efficiency, on one hand, and increasing stocking density and the share of grassland on farm land, on the other hand, may result in a reduction of all the impacts per kilogram of product. Dairy efficiency is one of the parameters that mainly influences profitability, expressed as IOFC, of a dairy farm; in fact, they are in the same area of Figure 3. Stocking density and feed self-sufficiency are on the opposite sides of the graph in Figure 3 and inversely related as a consequence of the higher amount of feeds generally bought from the market in the high-stocking density farms. Figure 4 shows the multivariate correlation between farm characteristics and environmental impacts per hectare of land. All environmental impact categories are close to each other, to the percentage of land for maize silage, and to the stocking density. On the first dimension (principal component 1), which explains $50.8 \%$ of the variance, all impact categories, expressed on unit of land, are inversely related to feed self-sufficiency.

The Pearson correlation analysis identified stocking density and feed self-sufficiency as the major drivers of environmental burden per hectare of farm land for all the impact categories. In particular, global warming ( $\mathrm{kg}$ of $\mathrm{CO}_{2}$-equivalent/ha of farm land) showed a strong positive correlation with stocking density $(\mathrm{r}=0.91$; $P<0.001)$ and a negative correlation with feed selfsufficiency $(\mathrm{r}=-0.71 ; P<0.001)$. Significant positive correlations were shown between the percentage of land used to grow maize for silage and all on-farm impact categories, especially acidification and eutrophication (0.55; $P<0.01$ and $0.58 ; P<0.01$, respectively).

Figure 5 shows the relationship between stocking density and eutrophication, expressed both per kilogram of FPCM and per hectare of farm land. The number of LU per hectare did not affect the emission per kilogram of milk, whereas it is a key point when the impact is expressed in land units.

\section{Farming Intensity and Environmental Performances}

The cluster analysis clearly identified 3 groups of farms differing in terms of intensity level (Table 8). The first one (high) included 10 farms characterized by a high level of intensification: high milk production per hectare, high percentage of arable land on total land, large land area sowed with maize for silage, high 


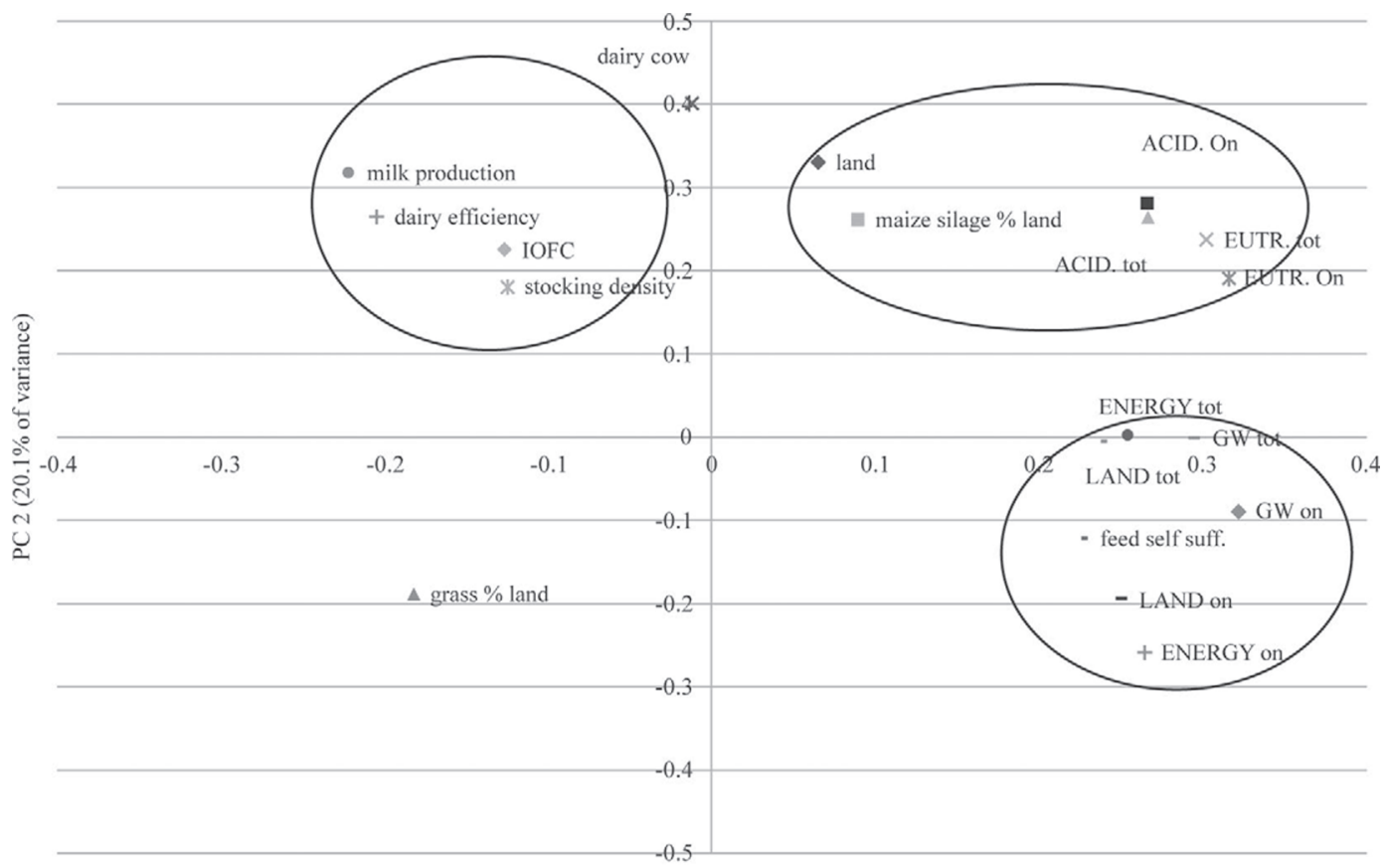

PC $1(38.7 \%$ of variance)

Figure 3. Principal component analysis (environmental impact expressed per kilogram of fat- and protein-corrected milk). $\mathrm{PC}=$ principal component; $\mathrm{GW}=$ global warming ( $\mathrm{kg}$ of $\mathrm{CO}_{2}$ equivalents); EUTR = eutrophication ( $\mathrm{g}$ of $\mathrm{PO}_{4}$ equivalents); $\mathrm{ACID}=$ acidification ( $\mathrm{g}$ of $\mathrm{SO}{ }_{2}$ equivalents); LAND = land use $\left(\mathrm{m}^{2}\right)$; ENERGY = energy use $(\mathrm{MJ})$; tot $=$ total impact; on $=$ on-farm fraction of impact; IOFC $=$ income over feed $\operatorname{cost}(€ /$ cow per day $) ;$ IOFC $=$ income over feed cost $(€ /$ cow per day $)$.

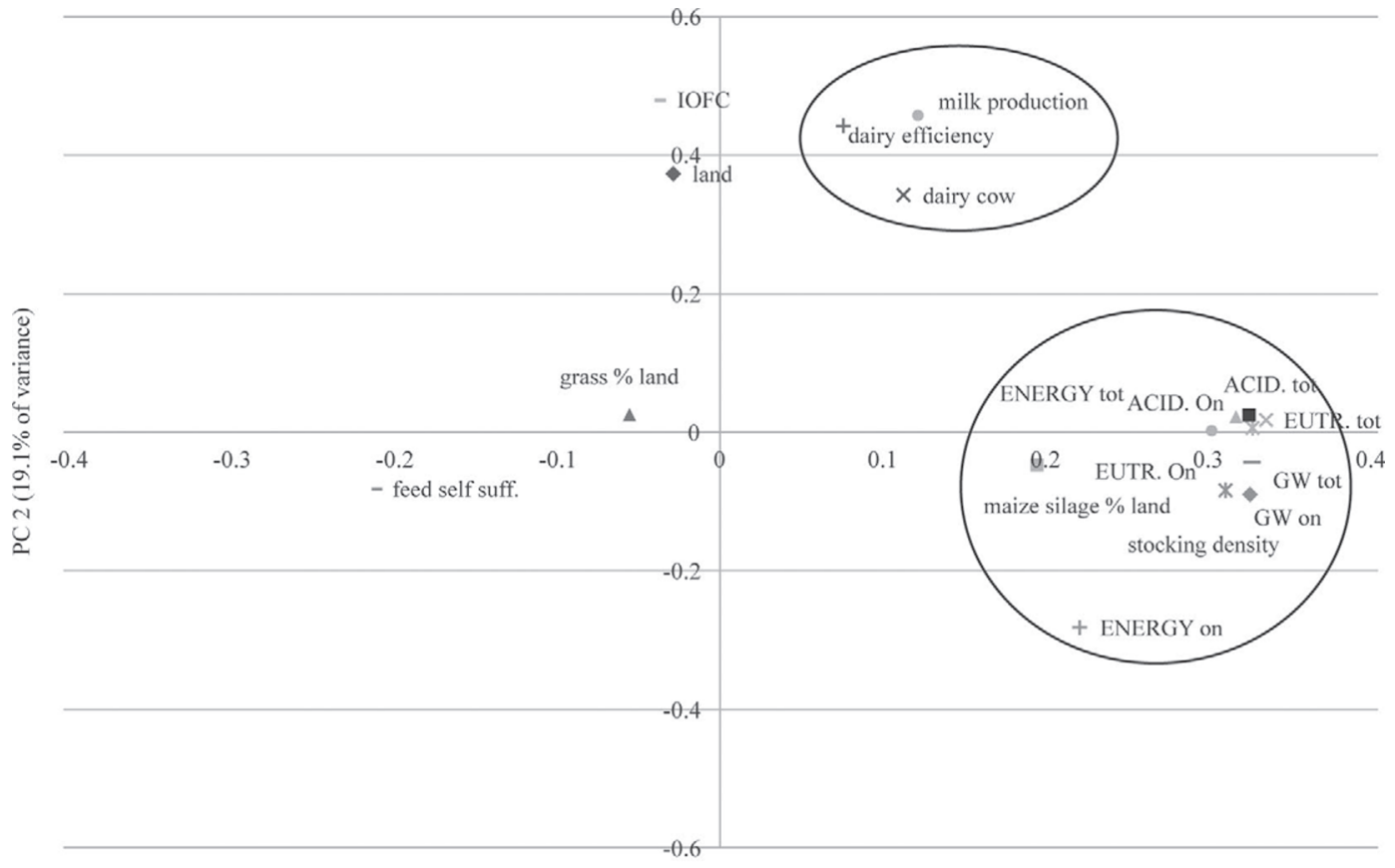

PC $1(50.8 \%$ of variance $)$

Figure 4. Principal component analysis (environmental impact expressed per hectare of farm land). $\mathrm{PC}=$ principal component; $\mathrm{GW}=$ global warming ( $\mathrm{kg}$ of $\mathrm{CO}_{2}$ equivalents); eutrophication ( $\mathrm{g}$ of $\mathrm{PO}_{4}$ equivalents); $\mathrm{ACID}=$ acidification $\left(\mathrm{g}\right.$ of $\mathrm{SO}_{2}$ equivalents); ENERGY = energy use $(\mathrm{MJ})$; tot $=$ total impact; on $=$ on-farm fraction of impact. 
Table 6. Eigenvectors corresponding to the principal components (PC) retained for the 28 dairy farms (impacts expressed per kilogram of fatand protein-corrected milk; FPCM); the first 5 PC had eigenvalues greater than 1

\begin{tabular}{|c|c|c|c|c|c|c|}
\hline Item & Unit & PC 1 & PC 2 & PC 3 & $\mathrm{PC} 4$ & $\mathrm{PC} 5$ \\
\hline Maize land for silage & $\%$ land & 0.09 & 0.26 & -0.29 & -0.25 & 0.07 \\
\hline Dairy cows & no. & -0.01 & 0.40 & 0.08 & -0.02 & -0.55 \\
\hline Stocking density & $\mathrm{LU}^{1} / \mathrm{ha}$ & -0.13 & 0.18 & -0.48 & -0.03 & -0.06 \\
\hline Milk production & $\mathrm{kg}$ of $\mathrm{FPCM} / \mathrm{cow}$ per day & -0.22 & 0.32 & 0.17 & 0.12 & 0.27 \\
\hline Dairy efficiency & $\mathrm{kg}$ of milk/kg of DMI & -0.20 & 0.27 & 0.23 & -0.01 & 0.33 \\
\hline Global warming on farm & $\mathrm{kg}$ of $\mathrm{CO}_{2}$-equivalent & 0.32 & -0.09 & -0.14 & -0.03 & -0.10 \\
\hline Acidification total & $\mathrm{g}$ of $\mathrm{SO}_{2}$-equivalent & 0.27 & 0.28 & -0.08 & 0.07 & 0.17 \\
\hline Acidification on farm & $\mathrm{g}$ of $\mathrm{SO}_{2}$-equivalent & 0.27 & 0.27 & -0.08 & -0.04 & 0.15 \\
\hline Eutrophication total & $\mathrm{g}$ of $\mathrm{PO}_{4}$-equivalent & 0.30 & 0.24 & -0.06 & 0.16 & 0.15 \\
\hline Eutrophication on farm & $\mathrm{g}$ of $\mathrm{PO}_{4}$-equivalent & 0.32 & 0.19 & -0.04 & -0.13 & 0.10 \\
\hline Energy use total & MJ & 0.25 & 0.00 & 0.09 & 0.38 & 0.24 \\
\hline Energy use on farm & MJ & 0.26 & -0.26 & 0.05 & -0.28 & 0.04 \\
\hline
\end{tabular}

${ }^{1} \mathrm{LU}=$ livestock units.

${ }^{2} \mathrm{IOFC}=$ income over feed cost

stocking density, high milk yield per cow, high dairy efficiency, high use of concentrate and maize silage in the cow rations instead of grass hay. The second cluster (medium) consisted of 7 farms less intensive in comparison with the farms of first cluster. The third group (low) included 11 farms identified as the least intensive on the basis of their characteristics.

Total farm land was different among the 3 groups, with the highest value in the medium cluster and lower values in the others. The percentage of arable land of the low group was lower compared with the other 2 groups; high had the higher quota of land used to grow maize for silage in comparison with the low group. The number of livestock units showed the same trend among the groups observed for the farm land. Stocking rate was generally high; in the high group it was particularly elevated compared with the other groups. The milk production levels of high and medium were higher compared with low; similarly, the dairy efficiency, which is strongly related to the level of productivity, showed better results in high and medium farms. High farms had lower feed self-sufficiency compared with the

Table 7. Eigenvectors corresponding to the principal components (PC) retained for the 28 dairy farms (impacts expressed per hectare); the first 4 PC had eigenvalues greater than 1

\begin{tabular}{|c|c|c|c|c|c|}
\hline Item & Unit & PC 1 & PC 2 & PC 3 & $\mathrm{PC} 4$ \\
\hline Maize land for silage & $\%$ land & 0.20 & -0.05 & 0.40 & 0.15 \\
\hline Permanent grassland & $\%$ land & -0.06 & 0.03 & -0.58 & -0.32 \\
\hline Stocking density & no. & 0.31 & -0.08 & -0.08 & -0.10 \\
\hline Milk production & $\mathrm{kg}$ of $\mathrm{FPCM}^{2} /$ cow per day & 0.12 & 0.46 & -0.20 & 0.17 \\
\hline Dairy efficiency & $\mathrm{kg}$ of milk/ $\mathrm{kg}$ of DMI & 0.08 & 0.44 & -0.16 & 0.35 \\
\hline Global warming on farm & $\mathrm{kg}$ of $\mathrm{CO}_{2}$-equivalent & 0.33 & -0.09 & -0.04 & -0.08 \\
\hline Acidification total & $\mathrm{g}$ of $\mathrm{SO}_{2}$-equivalent & 0.33 & 0.03 & 0.03 & 0.05 \\
\hline Acidification on farm & $\mathrm{g}$ of $\mathrm{SO}_{2}$-equivalent & 0.32 & 0.02 & 0.06 & 0.06 \\
\hline Eutrophication total & $\mathrm{g}$ of $\mathrm{PO}_{4}$-equivalent & 0.34 & 0.02 & 0.02 & 0.01 \\
\hline Eutrophication on farm & $\mathrm{g}$ of $\mathrm{PO}_{4}$-equivalent & 0.33 & 0.01 & 0.11 & 0.05 \\
\hline Energy use total & MJ & 0.30 & 0.00 & -0.11 & 0.03 \\
\hline Energy use on farm & MJ & 0.22 & -0.28 & 0.10 & 0.18 \\
\hline
\end{tabular}

${ }^{1} \mathrm{LU}=$ livestock units.

${ }^{2} \mathrm{FPCM}=$ fat- and protein-corrected milk.

${ }^{3} \mathrm{IOFC}=$ income over feed cost 
Table 8. Characteristics of the clusters

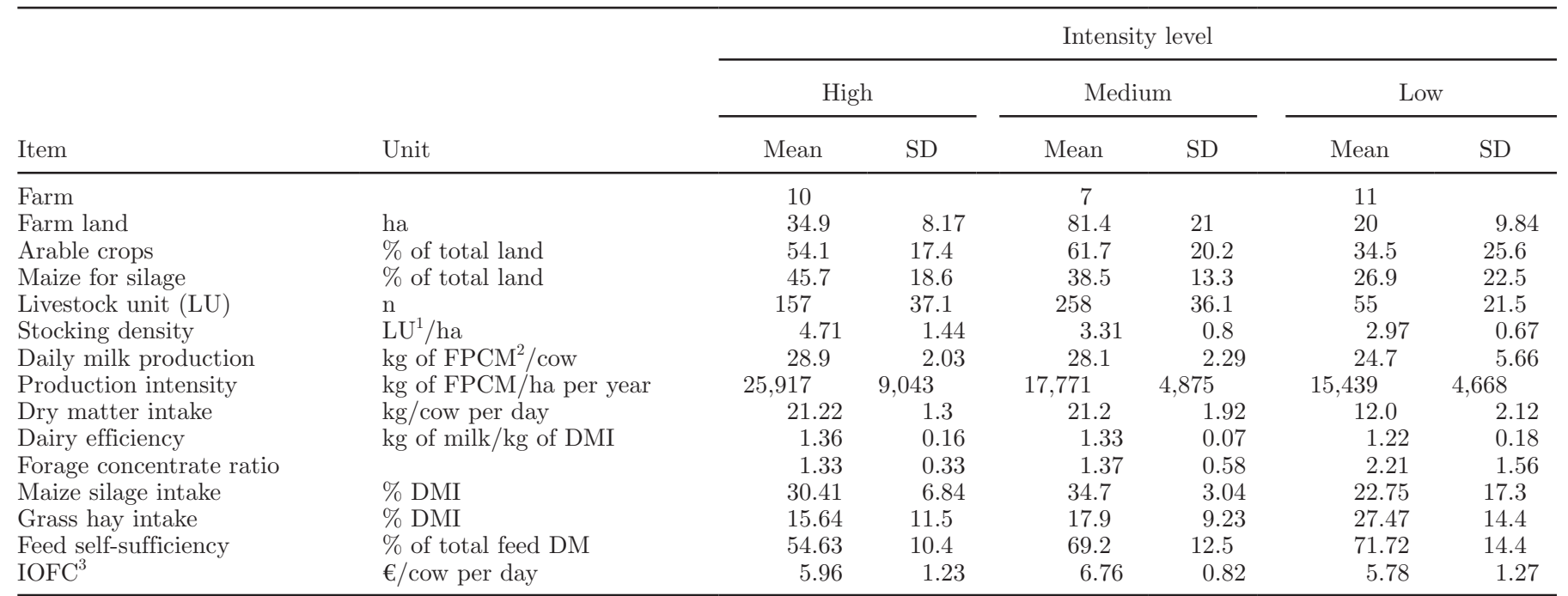

${ }^{1} \mathrm{LU}=$ livestock units.

${ }^{2} \mathrm{FPCM}=$ fat- and protein-corrected milk.

${ }^{3} \mathrm{IOFC}=$ income over feed cost.

other groups which had similar values. Considering the economic performances, no differences were observed between the average IOFC of the 3 clusters.

Analyzing the environmental impact on the product basis, only few differences were observed among the groups, and overall they should be considered similar (Table 9). Low farms showed higher on-farm energy use compared with the high ones. High farms had lower on-farm land use impact compared with the other 2

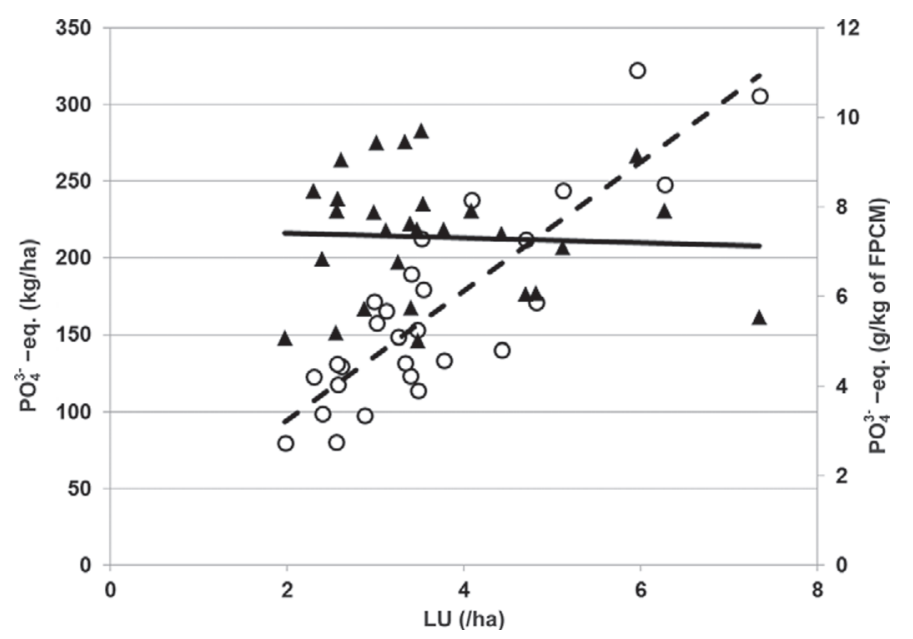

Figure 5. Relation between stocking density and eutrophication expressed per kilogram of fat- and protein-corrected milk (FPCM) and per hectare of farm land. Open circles $(\bigcirc)$ represent eutrophication per hectare and stocking density: $\mathrm{y}=42.025 \mathrm{x}+10.561 ; \mathrm{R}^{2}=$ 0.74. Triangles $(\boldsymbol{\Lambda})$ represent eutrophication per kilogram of FPCM and stocking density: $\mathrm{y}=-0.0543 \mathrm{x}+7.5317 ; \mathrm{R}^{2}=0.0025 . \mathrm{LU}=$ livestock unit. groups, whereas low had lower off-farm land use than high and medium.

The results change widely if the environmental impacts are evaluated on land unit, as shown in Table 10. High had higher total environmental impact per hectare of farm land for all the categories in comparison to the other 2 groups, which were similar to each other. A similar trend was observed for on-farm GWP, acidification, and eutrophication, which were higher in high than in medium and low. No differences were found regarding on-farm energy use.

\section{DISCUSSION}

\section{Environmental Impacts of Milk Unit}

The estimated GWP for the production of $1 \mathrm{~kg}$ of FPCM was comparable to the value found by Guerci et al. (2013) and in agreement with Castanheira et al. (2010), who similarly obtained a higher contribution of on-farm activities to GHG emission compared with off-farm activities. The acidification and the eutrophication potentials were similar to Castanheira et al. (2010), but higher compared with findings reported by O'Brien et al. (2012) and Basset-Mens et al. (2009). Total nonrenewable energy use was consistent with the results reported by Thomassen et al. (2008) for conventional Dutch dairy farms. Considering land use, the total impact and on-farm contribution were similar to O'Brien et al. (2012) and Basset-Mens et al. (2009). The contributions of the different substances to GWP were comparable with Castanheira et al. (2010). 
Table 9. Environmental impacts expressed per kilogram of fat- and protein-corrected milk corresponding to each cluster of farms

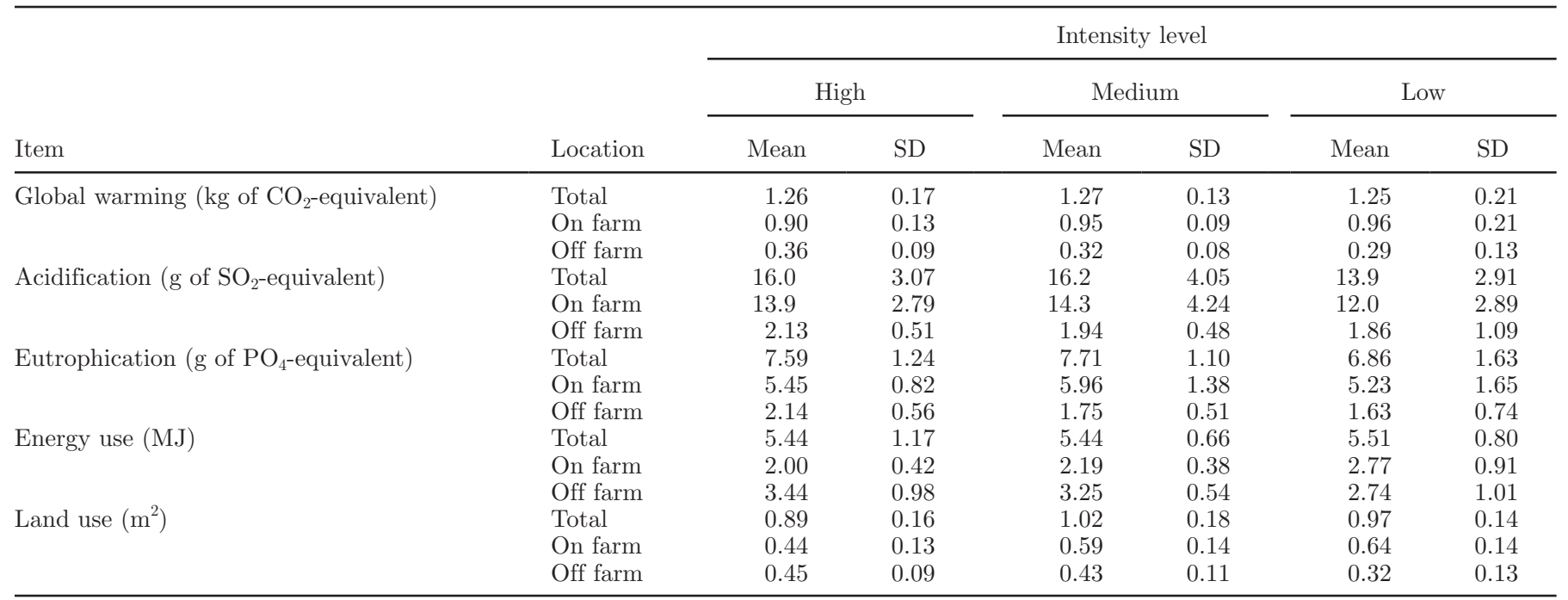

Similarly, several other studies reported $\mathrm{CH}_{4}$ to be the predominant contributor to the total climate change emissions (Flysjö et al., 2011; Kristensen et al., 2011; O'Brien et al., 2012), whereas Thomassen et al. (2008) found a methane contribution to total climate change of only $34 \%$ in the conventional system and of $43 \%$ in the organic system. Enteric methane is generally recognized as the major driver of GHG emissions in milk production, and the abatement of enterically derived $\mathrm{CH}_{4}$ is considered one of the most promising strategies for the reduction of GHG emissions from the dairy sector (Mc Geough et al., 2012).

The main contribution of ammonia to total acidification potential was found also by Thomassen et al. (2008) and Castanheira et al. (2010), who observed that $\mathrm{NH}_{3}$ emissions have a strong impact on the total acidification potential, whereas $\mathrm{SO}_{2}$ and $\mathrm{NOx}$ play a minor role. Castanheira et al. (2010) reported $\mathrm{NH}_{3}$ and $\mathrm{NO}_{3}$ as the major contributors to total eutrophication potential, whereas Thomassen et al. (2008) found phosphate to be more important in terms of impact on eutrophication. In the study of O'Brien et al. (2012), nitrate losses occurring on-farm were around $90 \%$ for the seasonal grass-based dairy system, but only about $30 \%$ for the confinement dairy system.

\section{Interaction Between Farm Characteristics and Environmental Impact}

The negative relationships shown by the PCA between total environmental impact per milk unit, on one side, and dairy efficiency and milk production level, on the other, are in agreement with numerous results from the literature. In fact, feed conversion efficiency of the

Table 10. Environmental impacts expressed per hectare corresponding to each cluster of farms

\begin{tabular}{|c|c|c|c|c|c|c|c|}
\hline \multirow[b]{2}{*}{ Item } & \multirow[b]{2}{*}{ Location } & \multicolumn{6}{|c|}{ Intensity level } \\
\hline & & Mean & $\mathrm{SD}$ & Mean & $\mathrm{SD}$ & Mean & $\mathrm{SD}$ \\
\hline \multirow[t]{3}{*}{ Global warming ( $\mathrm{kg}$ of $\mathrm{CO}_{2}$-equivalent) } & Total & 36,269 & 10,026 & 26,094 & 8,130 & 22,475 & 5,907 \\
\hline & On farm & 25,992 & 7.500 & 19,384 & 5,542 & 16,935 & 3,618 \\
\hline & Off farm & 10,277 & 3,088 & 6,711 & 2,845 & 5,540 & 3,442 \\
\hline Acidification ( $\mathrm{g}$ of $\mathrm{SO}_{2}$-equivalent) & Off farm & 60.0 & 17.8 & 40.2 & 18.2 & 36.2 & 28.6 \\
\hline \multirow[t]{3}{*}{ Eutrophication (g of $\mathrm{PO}_{4}$-equivalent) } & Total & 218 & 65.6 & 155 & 31.6 & 123 & 35.0 \\
\hline & On farm & 158 & 51.7 & 118 & 22.6 & 92.0 & 24.5 \\
\hline & Off farm & 60.3 & 18.2 & 37.1 & 19.8 & 30.7 & 18.3 \\
\hline \multirow[t]{3}{*}{ Energy use (MJ) } & Total & 152,327 & 36,184 & 111,278 & 32,997 & 99,317 & 26,930 \\
\hline & On farm & 56,063 & 12,714 & 43,844 & 8,653 & 47,436 & 10,663 \\
\hline & Off farm & 96,264 & 28,116 & 67,434 & 26,867 & 51,881 & 30,655 \\
\hline
\end{tabular}


animals is known to be an effective strategy in mitigating the environmental impact per unit of product (Hermansen and Kristensen, 2011; Yan et al., 2013); according to Capper et al. (2008), a general increase in productivity might positively affect the environmental sustainability of milk. Guerci et al. (2013) showed that farming strategies based on high production intensity and high dairy efficiency could mitigate environmental impact per kilogram of milk. The mitigation effect of enhancing dairy efficiency is based on the dilution of environmental costs associated with maintenance. Moreover high-producing cows usually receive low-fiber rations, reducing their methane emission per kilogram of milk.

The negative correlation between stocking density and total impact (per kilogram of FPCM) is a little surprising, especially when eutrophication and acidification potentials are considered. But farms with high stocking density were also characterized by high production levels and high dairy efficiency.

Grassland, instead of arable land, seemed to have a positive effect on the environmental impact, but its role was not clear due to the opposite effects of many factors. Generally grassland needs less fertilization than arable land and this has positive effects on GWP, eutrophication, and acidification, but arable crops (e.g., maize silage) have higher yield per hectare and require less field operations and less energy compared with grass hay production (Rotz et al., 2010).

Profitability, expressed as IOFC, shows a negative relationship with total environmental impact per kilogram of FPCM. Farms with cows more efficient in converting feed to milk have higher income per cow and lower impacts per milk unit.

Regarding environmental impact per hectare of land, PCA showed that the farm management characteristics mostly related to the different impact categories were stocking density and percentage of land for maize silage production. High LU per hectare means a high quantity of organic nitrogen on soil and low feed self-sufficiency. With respect to percentage of land for maize silage production, its positive relationship with environmental impact per hectare depends mainly on the high demand of maize in terms of nitrogen application (organic and chemical), which is positively related to environmental impact per unit of land, as found by Casey and Holden (2005).

\section{Farming Intensity and Environmental Performances}

The current study did not show any difference between the environmental impact per milk unit of the 3 clusters of farms, despite important differences among the groups in terms of farm characteristics and farming intensity. On the contrary, when the functional unit was the hectare of farm land, most of the impacts were much higher in the group of farms with high intensity levels. In general, intensification, defined as increased output per hectare, invariably led to increased emissions when expressed on an area basis; however, the result was less obvious when expressed on a product basis (Crosson et al., 2011). Basset-Mens et al. (2009) highlighted better environmental performances for the low-input dairy systems compared with more intensive systems from both a product and local perspective; similar results were obtained by O'Brien et al. (2012) for a grass-based farm versus a confinement system. van der Werf et al. (2009) observed no difference in terms of environmental impact between conventional and organic dairy systems when milk sold was considered as functional unit; however, on a land basis, the conventional systems showed a significantly higher environmental burden compared with the organic systems. Similar results were found by Haas et al. (2001), who reported significantly worse environmental performances in the intensive system than in the extensive system when the impact was expressed on land unit. Casey and Holden (2005) found a significant positive linear correlation between stocking rate and the amount of $\mathrm{CO}_{2}$-equivalent per hectare, but no relationship between stocking rate and GHG emissions per kilogram of milk. Similarly, Oudshoorn et al. (2011) found that no correlation between surplus $\mathrm{N}$ per hectare and emission of GHG per kilogram of ECM existed.

As a consequence, when the environmental impacts related to the product unit are considered, the identification of the more sustainable production strategy seems to be difficult. Several studies compared organic versus conventional farms or grass-based versus confined farms; some authors attributed better environmental performances to the low-input systems (Belflower et al., 2012; O'Brien et al., 2012), others associated the more intensive systems with a potential reduction of the environmental pressure (Thomassen et al., 2008; Kristensen et al., 2011), still other researchers reported different results depending on the impact category considered (Cederberg and Mattsson, 2000).

\section{CONCLUSIONS}

When assessing the environmental impact per milk unit, it is difficult to clearly identify the relationship between farming intensity and environmental performances, despite important differences in terms of farm intensification level, management, and structural characteristics. However, the PCA showed that some characteristics related to farming intensification, particularly milk production per cow, dairy efficiency, and 
stocking density, were negatively related to the impact per kilogram of product; this suggests a role of these factors in the mitigation strategy of the environmental impact of milk production on a global scale. Besides an important role in global environmental impact (i.e., climate change), livestock systems are often responsible for local and not less important impacts (i.e., eutrophication of soils and water). Considering the environmental burden on a local perspective, the impacts were positively associated with the intensification level.

\section{ACKNOWLEDGEMENTS}

This research was supported by Plan for R\&S (Research and Development), Region of Lombardy DG Agricoltura, Italy. Project no. 1726-Individuazione di modelli di aziende zootecniche per produzioni di eccellenza di latte e derivati.

\section{REFERENCES}

Alvarez, A., J. del Corral, D. Solís, and J. A. Pérez. 2008. Does intensification improve the economic efficiency of dairy farms? J. Dairy Sci. 91:3693-3698.

AOAC International. 1995. Official Methods of Analysis. 15th ed. AOAC International, Washington, DC.

AOAC International. 1998. Official Methods of Analysis. 16th ed. AOAC International, Washington, DC.

Baldoni, R., and L. Giardini. 2002. Coltivazioni Erbacee, Foraggere e Tappeti Erbosi. Pàtron Editore, Bologna, Italy.

Basset-Mens, C., S. Ledgard, and M. Boyes. 2009. Eco-efficiency of intensification scenarios for milk production in New Zealand. Ecol. Econ. 68:1615-1625.

Belflower, J. B., J. K. Bernard, D. K. Gattie, D. W. Hancock, L. M. Risse, and C. A. Rotz. 2012. A case study of the potential environmental impacts of different dairy production systems in Georgia. Agric. Syst. 108:84-93.

Capper, J. L., E. Castañeda-Gutiérrez, R. A. Cady, and D. E. Bauman. 2008. The environmental impact of recombinant bovine somatotropin (rbST) use in dairy production. Pages 9668-9673 in Proc. Natl. Acad. Sci. USA, 15th ed. University of Illinois, Urbana.

Casey, J. W., and N. M. Holden. 2005. The relationship between greenhouse gas emissions and the intensity of milk production. Ireland. J. Environ. Qual. 34:429-436.

Castanheira, É. G., A. C. Dias, L. Arroja, and R. Amaro. 2010. The environmental performance of milk production on a typical Portuguese dairy farm. Agric. Syst. 103:498-507.

Cederberg, C., and B. Mattsson. 2000. Life cycle assessment of milk production-A comparison of conventional and organic farming. J. Clean. Prod. 8:49-60.

Cornell-Penn-Miner. 2004. CPM Dairy. Dairy cattle ration analyzer, version 3.0.6. Cornell University, Ithaca, NY.

Crosson, P., L. Shalloo, D. O'Brien, G.J. Laniganc, P.A. Foley, T.M. Boland, and D.A. Kenny. 2011. A review of whole farm systems models of greenhouse gas emissions from beef and dairy cattle production systems. Anim. Feed Sci. Tech. 166:29-45. http://dx.doi. org/10.1016/j.anifeedsci.2011.04.001.

Ecoinvent. 2007. Ecoinvent Centre 2007, Ecoinvent Data v2.0-Final reports Ecoinvent 2000 No. 1-15. Swiss Centre for Life Cycle Inventories, Dübendorf, Switzerland.

EEA (European Environment Agency). 2009a. 4.B Animal husbandry and manure management GB2009 update. From the EMEP/EEA air pollutant emission inventory guidebook 2009. Accessed May 2012. http://www.eea.europa.eu/publications/emep-eea-emissioninventory-guidebook-2009/part-b-sectoral-guidance-chapters/4- agriculture/4-b/4-b-animal-husbandry-and-manure-management. $\mathrm{pdf} /$ view.

EEA (European Environment Agency). 2009b. 4.D Crop production and agricultural soils. From the EMEP/EEA air pollutant emission inventory guidebook 2009. Accessed May 2012. http://www.eea. europa.eu/publications/emep-eea-emission-inventory-guidebook2009/part-b-sectoral-guidance-chapters/4-agriculture/4-d/4-dcrop-production-and-agricultural-soils.pdf/view.

Ellis, J. L., E. Kebreab, N. E. Odongo, B. W. McBride, E. K. Okine, and J. France. 2007. Prediction of methane production from dairy and beef cattle. J. Dairy Sci. 90:3456-3466.

EPD (Environmental Product Declarations) 2008. SimaPro 7.7.3 PhD,

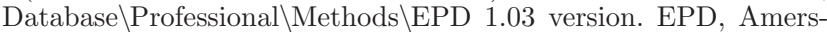
foort, the Netherlands.

Ewan, R. C. 1989. Predicting the energy utilization of diets and feed ingredients by pigs. Pages 215-218 in Energy Metabolism of Farm Animals. Y. van der Honing and W.H. Close, ed. EAAP Publication No. 43. Pudoc, Wageningen, the Netherlands.

Flysjö, A., M. Henriksson, C. Cederberg, S. Ledgard, and J. E. Englund. 2011. The impact of various parameters on the carbon footprint of milk production in New Zealand and Sweden. Agric. Syst. 104:459-469.

Gerber, P., T. Vellinga, C. Opio, B. Henderson, and H. Steinfeld. 2010. Greenhouse Gas Emissions from the Dairy Sector. A Life Cycle Assessment. Food and Agriculture Organization of the United Nations, Animal Production and Health Division, Rome, Italy.

Guerci, M., L. Bava, M. Zucali, A. Sandrucci, C. Penati, and A. Tamburini. 2013. Effect of farming strategies on environmental impact of intensive dairy farms in Italy. J. Dairy Res. 80:300-308.

Haas, G., F. Wetterich, and U. Köpke. 2001. Comparing intensive, extensified and organic grassland farming in southern Germany by process life cycle assessment. Agric. Ecosyst. Environ. 83:43-53.

Hermansen, J. E., and T. Kristensen. 2011. Management options to reduce the carbon footprint of livestock products. Anim. Front. 1:33-39.

Hutjens, M. F. 2007. Practical approaches to feed efficiency and applications on the farm. Penn State Dairy Cattle Nutrition Workshop, November 13-14, Grantville, PA. Accessed May 2012. http:// www.dairyweb.ca/Resources/PDCNW2007/Hutjens.pdf.

IDF (International Dairy Federation). 2010. A common carbon footprint approach for dairy. The IDF guide to standard lifecycle assessment methodology for the dairy sector. In the Bulletin of the IDF No 445/2010. International Dairy Federation, Brussels, Belgium.

INRA (Institut national de la recherche agronomique). 2007. Alimentation des bovins, ovins et caprins. Besoins des animaux - Valeurs des aliments. Tables Inra 2007. INRA, Versaille, France.

IPCC (Intergovernmental Panel on Climate Change). 2006a. Emissions from livestock and manure management. Chapter 10 in IPCC Guidelines for National Greenhouse Gas Inventories. Vol. 4: Agriculture, Forestry and Other Land Use. Accessed May 2012 http://www.ipcc-nggip.iges.or.jp/public/2006gl/pdf/4_Volume4/ V4_10_Ch10_Livestock.pdf.

IPCC (Intergovernmental Panel on Climate Change). 2006b. $\mathrm{N}_{2} \mathrm{O}$ Emissions from managed soils, and $\mathrm{CO}_{2}$ emissions from lime and urea application. Chapter 11 in IPCC Guidelines for National Greenhouse Gas Inventories. Vol. 4: Agriculture, Forestry and Other Land Use. Accessed May 2012. http://www.ipcc-nggip.iges. or.jp/public/2006gl/pdf/4_Volume4/V4_11_Ch11_N2O\&CO2. pdf.

IPCC (Intergovernmental Panel on Climate Change). 2007. Direct global warming potential. In IPCC Fourth Assessment Report. Climate Change 2007: Working Group I: The Physical Science Basis. Accessed June 2012. http://www.ipcc.ch/publications_and_ data/ar4/wg1/en/ch2s2-10-2.html.

ISTAT. 2012. Istituto nazionale di statistica. Accessed Dec. 2012 http://www3.istat.it/.

Kristensen, T., L. Mogensen, M. T. Knudsen, and J. E. Hermansen. 2011. Effect of production system and farming strategy on greenhouse gas emissions from commercial dairy farms in a life cycle approach. Livest. Sci. 140:136-148. 
Mc Geough, E. J., S. M. Little, H. H. Janzen, T. A. McAllister, S. M. McGinn, and K. A. Beauchemin. 2012. Life-cycle assessment of greenhouse gas emissions from dairy production in eastern Canada: A case study. J. Dairy Sci. 95:5164-5175.

Mertens, D. R. 2002. Gravimetric determination of amylase-treated neutral detergent fiber in feeds using refluxing in beakers or crucibles: Collaborative study. J. AOAC Int. 85:1217-1240.

Nemecek, T., and T. Kägi. 2007. Life cycle inventories of Swiss and European agricultural production systems. Final Report Ecoinvent V2.0 No. 15a. Agroscope Reckenholz-Taenikon Research Station, Swiss Centre for Life Cycle Inventories, Zurich and Dübendorf, Switzerland

Nielsen, P. H., A. M. Nielsen, B. P. Weidema, R. Dalgaard, and N Halberg. 2003. Life Cycle Assessment food database. Accessed May 2012. http://www.lcafood.dk.

O’Brien, D., L. Shalloo, J. Patton, F. Buckley, C. Grainger, and M. Wallace. 2012. A life cycle assessment of seasonal grass-based and confinement dairy farms. Agric. Syst. 107:33-46.

Oudshoorn, V., C. A. G. Sørensen, and I. J. M. de Boer. 2011. Economic and environmental evaluation of three goal-vision based scenarios for organic dairy farming in Denmark. Agric. Syst. 104:315-325.

Patyk, A., and G. A. Reinhardt. 1997. Düngemittel- Energie- und Stoffstrohmbilanzen (Fertilizer- Energy- and Massbalances). Vieweg, Heidelberg, Germany.

Penati, C., P. B. M. Berentsen, A. Tamburini, A. Sandrucci, and I. J. M. de Boer. 2011. Effect of abandoning highland grazing on nutri- ent balances and economic performance of Italian Alpine dairy farms. Livest. Sci. 139:142-149.

PRé Consultants. 2012. SimaPro 7.3.2 PhD, LCA software. Amersfoort, the Netherlands. Accessed May 2012. http://www.pre.nl.

Ribaudo, F. 2002. Prontuario di Agricoltura. Calderini Edagricole, Bologna, Italy.

Rotz, C. A., F. Montes, and D. S. Chianese. 2010. The carbon footprint of dairy production systems through partial life cycle assessment. J. Dairy Sci. 93:1266-1282

SAS Institute. 2001. User's Guide, Version 9.0. SAS Institute Inc. Cary, NC.

Thomassen, M. A., K. J. van Calker, M. C. J. Smits, G. L. Iepema, and I. J. M. de Boer. 2008. Life cycle assessment of conventional and organic milk production in the Netherlands. Agric. Syst. 96:95-107.

van der Werf, H. M. G., C. Kanyarushoki, and M. S. Corson. 2009. An operational method for the evaluation of resource use and environmental impacts of dairy farms by life cycle assessment. J. Environ. Manage. 90:3643-3652.

Van Soest, P. J., J. B. Robertson, and B. A. Lewis. 1991. Methods of dietary fiber, neutral detergent fiber and nonstarch polysaccharides in relation to animal nutrition. J. Dairy Sci. 74:3583-3597.

Yan, M. J., J. Humphreys, and N. M. Holden. 2013. Life cycle assessment of milk production from commercial dairy farms: The influence of management tactics. J. Dairy Sci. 96:4112-4124. 